\title{
Toll-Like Receptor 9
}

National Cancer Institute

\section{Source}

National Cancer Institute. Toll-Like Receptor 9. NCI Thesaurus. Code C96048.

Toll-like receptor 9 (1032 aa, $116 \mathrm{kDa}$ ) is encoded by the human TLR9 gene. This protein plays a role in the mediation of inflammatory signaling. 